first phase folds. Deformation by compaction is rejected because the overlying Lapa sandstone is not deformed.

The above features suggest that the sediments correspond to an esker. The deposit is part of the lowstand system tract of the $3^{\text {rd }}$ order sequence $S_{2}$ described by Canuto et al. (2001). - ( December 14, 2001 ) .

\footnotetext{
* Supported by FAPESP, No. 97/13973-2.

**E-mail: jrcanuto@usp.br
}

THE THIRD ORDER SEQUENCE STRATIGRAPHY OF THE ITARARÉ SUBGROUP (LATE PALEOZOIC) ACROSS PARANÁ BASIN*

José R. CANuto**, PAulo R. SAntos AND

Antonio C. Rocha-CAMPoS

Instituto de Geociências, USP, São Paulo, SP.

The Itararé Subgroup (late Paleozoic) on the eastern margin of the Paraná Basin is subdivided into seven $50-80 \mathrm{~m}$ thick, type I, third order sequences that correspond to fining-coarsening upward cycles. Sequences are bounded at base by an erosional unconformity that at the eastern margin of the basin is marked either by glacially striated and/or glaciotectonised bedrock, or intraformational, glacially striated surfaces.

Our depositional model considers that each erosional surface, usually overlain by subglacial tillite, records an advance of a grounded glacier. Higher up the glaciogenic section includes glacioterrestrial, glaciomarine and marine beds (tillites, flow diamictites, proglacial rhythmites with dropstones, outwash sandstone, etc.), deposited during retreat of the ice margin. The sequences culminate with marine shale documenting short-lived post-glacial transgression, and shallow-marine progradacional fluviatile-deltaic sandstone, associated to glacioisostatic rebound that followed retreat of the glacial margin.

This type of sequence was earlier identified in outcrop and is now recognized in the subsurface of the Paraná Basin, along an east-west cross-section trough wells 1-PT1PR, 1-RO-1-PR, 2-NA-1-PR and AMst-1-MT in Brazil, and Asunción 2 in Paraguay. Correlation of sequences in subsurface and outcrop was established lithostratigraphically from top to bottom, with reference to a datum represented by a widespread marine marker bed intercalated in the Rio Bonito Formation. Absence of basal S1 sequence in well 1-RO-1-PR may be related to its location on a basement high. Only the uppermost part of S1 is recorded in well AMst-1-MT due to the intercalation of a thick diabase sill (Cretaceous) between Itararé beds and the underlying Ponta Grossa Formation.

With exception of the two cases, the subsurface section shows a full sequential correspondence. Most sequences, however, thicken from SE-NW, almost doubling values found on the eastern margin of the Paraná Basin. This suggests higher subsidence rate towards west, that compensated the positive tectonic behavior of the adjacent Asunción arch and created adequate space to accommodate sediments supplied from the eastern flank of the Asunción arch. - (December 14, 2001 ) .

\footnotetext{
* Supported by FAPESP 97/13973-2.

**E-mail: jrcanuto@usp.br
}

\section{EXTRUSION-RELATED EXTENSIONAL SIGNATURES UNDER HIGH-PRESSURE NAPPE COMPRESSIONAL REGIME*}

Carlos H. G. Carvalho and Mario C. Campos-Neto

Instituto de Geociências, USP, São Paulo, SP.

Presented by Antonio C. Rocha-CAmpos

The Neoproterozoic nappe system exposed south of the São Francisco Craton underwent a minimum of $200 \mathrm{~km}$ of near-horizontal northeastward displacement. This nappe system comprises the south-southeast sector of Brasília Belt and piles up three tectonic settings (from top to bottom): the roots of a neoproterozoic magmatic arc (Socorro-Guaxupé Nappe); high-pression metassedimentary nappes (Três Pontas-Varginha, Carmo da Cachoeira, Aiuruoca-Andrelândia, Pouso Alto and Carvalhos klippe); parautochthonous medium-pressure nappes and duplexes.

In the southeast of Aiuruoca-Andrelândia Nappe, a brittle-ductile sinistral shear zone (Liberdade Shear Zone) limits the southern Alagoa Migmatites and may represent a lateral ramp for the eastern Lima Duarte Nappe. Close to Alagoa (MG), this shear zone turns E-W, breaking the nappe hind portion, in a southward normal-ductile movement.

North of this shear zone, the garnet-sillimatite bearing metassedimentary sequence lays over a gnaissicdiatexitic basement and is highly sliced by strata-like tourmaline-bearing granites. In the metassediments, main foliation $S_{2}$ is transposed by a normal-fault related thick protomilonitic $S_{2}$ ' foliation. In the gnaisses, southward transport is marked by shear-sense indicators such as S-C foliations and quartz sigmoids. A low-temperature, late brittle thrust system, overlaps the extensional structures.

Heading north, the end of this structural- 
metamorphic domain is marked by an antiform in gnaissic diatexites. A normal fault with average northeastward dip limits the fold and juxtaposes upper kianite-staurolite bearing micaxists. From this limit, the structural pattern of Aiuruoca-Andrelândia Nappe is homogeneous, with sinmetamorphic ductile shear-sense indicators to E-NE.

The alternating of extensional structures in a general compressive regime and in the hind portion of high-pressure nappe, is associated with the extrusion process and with the search, in the collisional orogen, of isostatic balance. - ( December 14, 2001 ).

\footnotetext{
* Supported by FAPESP 00/11390-4 and 98/15624-8.
}

\section{FACIES AND SEQUENCE STRATIGRAPHY OF THE ITARARÉ AND GUATÁ SUBGROUPS (LATE PALEO- ZOIC), NORTHERN PARANÁ BASIN, BRAZIL*}

Antonio M. Chaves-Junior and José R. Canuto**

Instituto de Geociências, USP, São Paulo, SP.

Presented by Antonio C. Rocha-CAmpos

Glacial advances and retreats influenced relative sea level change, concomitantly to the regional subsidence during the deposition of a $2^{\text {nd }}$ order Permo-Carboniferous sequence in northern Santa Catarina State, Paraná Basin.

According to Canuto's (1999) nomenclature, the following facies were recognized in the Itararé and in the lower part of the Guatá Subgroups: a) compacted massive diamictite; b) uncompacted massive diamictite; c) lenticular diamictite; d) low-angle, cross-bedded and truncated wave-ripple-laminated sandstone; e) truncated low-angle, cross-bedded, tabular sandstone; f) low-angle, bidirecional, cross-bedded, tabular sandstone; g) crossbedded, fining-upward sandstones; h) massive or laminated shale; i) massive siltstone; j) interlaminated very fine sandstone and silty shale. Some of them corresponding to diagnostic facies of facies associations (\#).

Facies associations recognized are: $A_{1}$, compacted massive (\#), uncompacted massive (\#) and lenticular diamictites; $A_{2}$, truncated low-angle cross-bedded tabular sandstone (\#); $\mathrm{A}_{3}$, massive or laminated shale (\#) and massive siltite (\#); $\mathrm{A}_{4}$, interlaminated (\#), low-angle cross-bedded and truncated wave ripple laminated sandstone and low-angle bidirecional cross-bedded tabular sandstone (\#); and corresponding, respectively, lowstand, transgressive, highstand and glacio-isostatic regressive system tracts.

In view of the recognized associations of facies, it is verified that the sedimentary succession comprises two partial $3^{\text {rd }}$ order sequences, representing the upper part of one (associations $\mathrm{A}_{3}$ and $\mathrm{A}_{4}$ ) and the basal and intermediate parts of the overlying one (associations $\mathrm{A}_{1}, \mathrm{~A}_{2}$ and $\left.\mathrm{A}_{3}\right)$.

The analysis of the sedimentary succession shows, from the base to the top, that the shales were deposited in a mudflat environment, followed by the deposition of sandstones in a lower shoreface setting, sandstones in upper shoreface, the interlaminated in tidal flat/foreshore, glacial advance, glacio-isostatic subsidence possibly until a compatible shoreface depth, disintegration and retreat of the glacier, slow rise of the sea level until the establishment of the foreshore/tidal flat, shoreface environment again due to a greater rise of the relative sea level than the last one, beginning of glacio-isostatic uplift by the final retreat of the glacier, return of the foreshore conditions, possibly still the backshore setting, and, finally, deltaic progradation over foreshore and/or backshore settings. - ( December 14, 2001 ).

* Supported by FAPESP 97/13973-2.

**E-mail: jrcanuto@usp.br.

\section{THE PIUMHI SUPERGROUP, SW-SÃO FRANCISCO CRATON, MG-BRAZIL}

Alexandre P. Chiarini ${ }^{1,2}$ And Hans D. Schorscher ${ }^{1}$

${ }^{1}$ Instituto de Geociências, USP, São Paulo, SP.

${ }^{2}$ BTX Serviços Geológicos, São Paulo, SP.

Presented by Antonio C. Rocha-Campos

Field work, petrographical and geochemical studies of the metavolcano-sedimentary sequence (VSS) of Piumhi-MG, a part of an Archaean or Palaeoproterozoic greenstone belt showed that current stratigraphical and petrographical classifications of this sequence require redefinition (Chiarini, 2001). Here, the VSS is formally defined as the Piumhi Supergroup, subdivided into: Lower and Upper groups (grupos Inferior and Superior) based on the Córrego Araras type-section. From base to top the Lower Group comprises: Andesitic Volcanic Unit (AVU), Magnesian Basaltic Volcanic Unit (MBVU) and Basaltic Volcanic Unit (BVU). The Upper Group, undivided here, comprises clastic and volcaniclastic metasediments with intercalated basic to acid volcanics. The Piumhi Supergroup exhibits middle greenschist facies metamorphism.

In the AVU predominate transitional tholeiitic to calc-alkaline basaltic andesites, dacites and rhyolites of fractional crystallization, altered by pre-metamorphic 